Ukraine] vid 04.06.2004r. № 04-5/1193. URL: https://zakon4.rada.gov.ua/ laws/show/v1193600-04 (accessed: 20.08.2020). (in Ukrainian)

5. Postanova Plenumu Verxovnogo Sudu Ukrayiny [Resolution of the Plenum of the Supreme Court of Ukraine] vid 18.12.2009r. № 15. URL: https://zakon.rada.gov.ua/laws/show/v0015700-09 (accessed: 20.08.2020). (in Ukrainian)

6. Pro vnesennya zmin do Zakonu Ukrayiny "Pro vidnovlennya platospromozhnosti borzhny'ka abo vy'znannya jogo bankrutom" [On Amendments to the Law of Ukraine "On Restoration of Debtor's Solvency or Recognition of Debtor's Bankruptcy"]: Zakon Ukrayiny [the Law of Ukraine] vid 22.12.2011r. № 4212-VI. URL: https://zakon.rada.gov.ua/laws/show/ 4212-17 (accessed: 20.08.2020). (in Ukrainian)

7. Radziviliuk V. Genezys nacyonalnogo zakonodatelstva Ukrayny o bankrotstve i problemy, s nym svyazannye [The genesis of the national legislation of Ukraine on bankruptcy and the problems associated with it] Legea si Viata (Молдова). 2013. № 12. S. 167-170. (in Russian)

8. Biryukov O.M. Suchasnyj stan rozvytku zakonodavstva pro bankrutstvo [The current state of development of bankruptcy legislation]. Universytetski naukovi zapysky. 2008. № 4(28). S. 100-103.

9. Butyrskyi A. Koncepciya udoskonalennya zakonodavstva pro nespromozhnist [The concept of improving the legislation on insolvency]. Pravo Ukrayiny. 2018. №6. S. 86-97. (in Ukrainian)

10. Kodeks Ukrayiny $z$ procedur bankrutstva [Bankruptcy Code of Ukraine] : Zakon Ukrayiny vid 18 zhovtnya 2018 № 2597-VIII https://zakon.rada.gov.ua/laws/show/2597-19\#Text (accessed: 25.08.2020). (in Ukrainian)

V. Radziviliuk, Dr of Law, Prof.

Taras Shevchenko National University of Kyiv, Kyiv, Ukraine,

R. Poliakov, Lawyer

Law Firm "Lex Advance", Kyiv, Ukraine

\title{
COMPETITIVE PROCESS DEVELOPMENT IN UKRAINE IN THE 2000s
}

The article deals with the chronology of the legal regulation for bankruptcy in Ukraine at the stage of its economic recovery, clarifies the essence of its elements, as well as the effectiveness of the entire legal mechanism and its individual components.

The authors pay attention to the legal regimentation of the bankruptcy procedure and to the legal acts that regulate its implementation. The main novelties and shortcomings of these acts and their impact on law enforcement practice and on the economy as a whole are highlighted. The article considers the approaches of the legislator to the settlement of the legal status of creditors, their representative bodies, the arbitration managers, as well as the implementation of certain court procedures applied to the debtor at different stages of bankruptcy legislation development.

It was found that the Bankruptcy Law, as amended in 2002, became one of the driving forces of Ukraine's economic growth. It is determined that the Recommendations of Supreme Economic Court of Ukraine have highlighted one of the key provisions (principles), in particular the priority of the Bankruptcy Law over other legal acts and the latter can be applied in insolvency as much as necessary and possible. It is substantiated that the Bankruptcy Law, as amended in 2011, contained both the development of judicial practice as well as revolutionary provisions and the achievement of technical progress in the field of the Internet, which contributed to bringing the bankruptcy proceedings to a higher level. It is argued that a number of provisions of this law were used in the preparation of the Commercial and Procedural Code of Ukraine and the Civil Procedural Code of Ukraine.

It is determined that a number of the most important provisions of the legislation of the period under study were not reflected in the latest bankruptcy legislation, in particular: clear conditions for initiating bankruptcy proceedings; variety of bankruptcy procedures applied to debtors with legal personality; indefinite circle of subjects of bankruptcy and those persons who are not included in the named circle.

Keywords: bankruptcy procedure, bankruptcy, insolvency, debtor, creditor, commercial court.

Bulletin of Taras Shevchenko National University of Kyiv. Legal Studies, 2020; 3 (114): 43-48

УДК: 349.2

DOI: https:doi.org/10.17721/1728-2195/2020/3.114-9
ISSN 1728-2195

(C) Taras Shevchenko National University of Kyiv, Publishing center "Kyiv University", 2020

I. Сахарук, канд. юрид. наук, доц. ORCID ID: 0000-0002-9146-2491

Київський національний університет імені Тараса Шевченка, Київ, Україна

\section{ТЕНДЕНЦІї ПРАВОВОГО РЕГУЛЮВАННЯ ЗАХИСТУ ВІД ПСИХОСОЦІАЛЬНИХ РИЗИКІВ НА РОБОТІ}

Статтю присвячено дослідженню психосоціальних ризиків як елемента системи охорони праці. Установлено, що посилена конкуренція, більш високі очікування щодо продуктивності та тривалості робочого часу й інші психосоціальні ризики сприяють усе напруженішому робочому середовищу. Визначено правові основи регламентації психологічних умов праці та внесено рекомендації щодо вдосконалення трудового законодавства у цій сфері. Проведено аналіз ключових психосоціальних ризиків у сфері праці в сучасний період. Досліджено основні технологічні трансформації та зміни в організації праці, які впливають на психологічну безпеку працівника. Особливу увагу зосереджено на питаннях протидії мобінгу та домаганням на роботі.

Ключові слова: умови праці, охорона праці, психосоціальні ризики, психологічні умови праці, психологічна безпека, психологічний клімат, управління охороною праці, нестандартні умови праці, цифрові платформи, мобіне, домагання.

ВСтУП. Згідно з доповіддю Глобальної комісії Міжнародної організації праці (МОП) із питань майбутнього сорери праці "Work for a Brighter Future" (2019) у світі, де щорічно майже 3 млн працівників продовжують помирати в результаті нещасних випадків і профзахворювань, настав час визнати, що безпека праці $є$ одним з основоположних принципів і прав у сфері праці [1, с. 39]. При цьому Міжнародна організація праці постійно наголошує на тому, що безпечні та здорові умови праці $€$ основою для гідної роботи (наприклад, Глобальна стратегія МОП з охорони праці 2003 р. [2], Декларація століття МОП щодо майбутнього сфери праці 2019 р. [3] тощо). Отже, безпека на робочому місці в сучасний період $є$ одним з актуальних питань у контексті реалізації концепції гідної праці. При цьому необхідним $€$ ство- рення правових основ для забезпечення не лише фрізичної, але і психологічної безпеки працівників.

Відповідно, важливою тенденцією у створенні безпечних та здорових умов праці є регулювання захисту від психосоціальних ризиків на робочому місці. Згідно $з$ доповіддю МОП "Safety and health at the heart of the future of work" (2019) психосоціальні ризики та стрес на роботі викликають усе більшу стурбованість у багатьох працівників по всьому світу [4, с. 1], а психосоціальні небезпеки сприяють усе напруженішому робочому середовищу [5, с. 2]. Всесвітня організація охорони здоров'я у Міжнародній класифрікації хвороб (10 і 11 видання) серед факторів впливу на здоров'я визначає професійне вигорання як синдром, що виникає внаслідок хронічного стресу на робочому місці [6] 
Метою статmі є дослідження теоретико-правових основ протидії психосоціальним ризикам на роботі, внесення пропозицій щодо вдосконалення національного трудового законодавства з метою врегулювання права працівника на належні психологічні умови праці.

\section{ВИКЛАД ОСНОВНОГО МАТЕРІАЛУ}

Правові основи регламентації психологічних умов праці. У сучасний період МОП розглядає психічне здоров'я як стан здоров'я та добробуту (індивідуального та колективного), за якого працівники усвідомлюють власні здібності та працюють продуктивно, впливаючи на трудовий колектив [5, с. 32], а стрес як шкідливу фрізичну та емоційну відповідь на дисбаланс між передбачуваними вимогами (на роботі) і наявними ресурсами та здібностями людей, щоб упоратися із цими вимогами [5, с. 4].

Як справедливо вказують Н. О. Губа, В. С. Кондратенко, компанії, які сучасно розвиваються, нині особливу увагу приділяють створенню найсприятливіших умов для роботи своїх працівників, оскільки розуміють, що рівень задоволеності працею впливає на якість їх роботи [7, с. 17]. Головними чинниками задоволеності своєю працею $є$ психологічні чинники, які відповідають безпосередньо за збереження цілісності свого Я, та побудови сприятливих психологічних умов для роботи в компанії $[7$, с. 19]. При цьому стрес, зумовлений роботою, залежить від організації роботи і виникає тоді, коли вимоги не відповідають або перевищують можливості, ресурси або потреби працівника, або коли знання чи здібності окремого працівника чи групи працівників не відповідають очікуванням організаційної культури підприємства [5, с. 4].

Фактори на робочому місці, які можуть викликати стрес, визначають психосоціальними небезпеками (ризиками). Наявність психосоціальних небезпек МОП визначила ще 1984 р., підкреслюючи динамічну взаємодію між умовами праці та особистими якостями працівників. Негативна взаємодія між ними може призвести до емоційних порушень, поведінкових проблем, біохімічних та нервово-гормональних змін, що представляє додаткові ризики психічних чи фрізичних захворювань. Навпаки, коли умови праці й особисті якості працівників перебувають у рівновазі, робота створює відчуття впевненості в собі, підвищує мотивацію, працездатність і покращує стан здоров'я [5, с. 5].

Якщо на початковому етапі діяльності МОП увага щодо охорони праці була зосереджена на питаннях фрізичної безпеки працівників і лише окремі положення регламентували питання психологічних умов праці, то сьогодні акценти зміщуються саме на психологічну безпеку. Так, відповідно до ст. 1 Конвенції МОП № 155 про безпеку й гігієну праці та виробниче середовище, термін "здоров'я" стосовно праці означає не тільки відсутність хвороби чи недуги; він також включає фрізичні та психічні елементи, які впливають на здоров'я і безпосередньо стосуються безпеки й гігієни праці [8]. А згідно зі ст. 1 Конвенції МОП № 161 про служби гігієни праці, на служби покладено профрілактичні фрункції та відповідальність за консультування роботодавця, працівників та їх представників із питань вимог щодо створення й підтримання безпечного та здорового виробничого середовища, яке сприятиме оптимальному фрізичному та психічному здоров'ю у зв'язку із трудовою діяльністю [9].

Право на належні, безпечні і здорові умови праці закріплено ст. 43 Конституції України [10], а також ст. 2 Кодексу законів про працю України [11], який при цьому не застосовує поняття "належні умови праці", регламентуючи лише безпечні і здорові умови. Водночас, ні глава КЗпП "Охорона праці", ні Закон України "Про охорону праці" не регламентують заходів щодо гарантування безпечних та належних психологічних умов праці.

Серед Цілей сталого розвитку 2016-2030 рр. визначено сприяння поступальному, усеохоплюючому та сталому економічному зростанню, повній і продуктивній зайнятості та гідній праці для всіх [12]. Указана ціль включає, зокрема, сприяння забезпеченню надійних $i$ безпечних умов праці для всіх трудящих, включаючи трудящих-мігрантів, особливо жінок-мігрантів, та осіб, які не мають стабільної зайнятості (п. 8.8). Крім того, ціль 3 містить завдання "Нарощувати потенціал усіх країн, особливо країн, що розвиваються, у сфері раннього попередження, зниження ризиків і регулювання національних і глобальних ризиків для здоров'я" [12]. Водночас, на національному рівні підціль 8.5 "Сприяти забезпеченню надійних та безпечних умов праці для всіх працюючих, зокрема шляхом застосовування інноваційних технологій у сфері охорони праці та промислової безпеки" регламентує лише індикатори щодо кількості потерпілих і загиблих від нещасних випадків на виробництві та частку працівників, зайнятих на роботах зі шкідливими умовами праці у загальній обліковій кількості штатних працівників. Відповідно, питання психологічних умов праці серед завдань щодо реалізації Цілей сталого розвитку відсутні.

У національній доктрині трудового права так само переважає розуміння охорони праці як дотримання норм техніки безпеки та виробничої санітарії і лише окремі науковці звертають увагу на психологічну безпеку працівника. Так, С.В.Вишновецька зауважує, що виробниче середовище має бути організоване так, щоб забезпечити не лише фрізичну безпеку працівника, а i психологічний коморорт його праці $[13$, с. 116]. О. А. Яковлєв указує, що здорові умови праці повинні передусім указувати на сукупність чинників, які впливають на професійну діяльність і за яких стан людини мав би характеризуватися повним психічним, фрізичним і моральним благополуччям [14, с. 129]. Авторський колектив підручника "Курс порівняльного трудового права" новим напрямом у розвитку законодавства України про охорону праці називає правове регулювання гарантування людині комфортного виробничого середовища, наголошуючи на необхідності концентрації уваги законодавця на забезпечення психологічної недоторканності і безпеки працівника [15, с. 234]. Відповідно, для належної регламентації психологічних умов праці як частини охорони праці на сьогодні необхідні і зміни на законодавчому рівні, і перегляд доктринальних підходів до змісту інституту охорони праці.

Напрями дослідження психосоціальних ризиків. Особливу увагу на необхідність посилення уваги до дослідження психосоціальних ризиків на робочому місці МОП звертає у звіті 2019 р. "Safety and health at the heart of the future of work. Building on 100 years of experience" [4, c. 56].

Аналіз цього звіту дозволяє визначити ключові напрями таких досліджень:

1) інтеграція психосоціальних ризиків в оцінки ризику як частини систем управління охороною праці 3 метою розробки цільових стратегій запобігання та управління небезпеками;

2) шляхи розвитку безпечного психологічного клімату на робочому місці;

3) вивчення впливу психосоціальних ризиків на роботі на фрізичне здоров'я працівників, включаючи серцево-судинні захворювання, захворювання шлунковокишкового тракту та розлади психічного здоров'я (вигорання, депресія тощо); 
4) визначення співвідношення надурочного робочого часу й малорухливої роботи на здоров'я працівників.

3 указаних напрямів лише перший пов'язаний першочергово 3 необхідністю вдосконалення законодавства, тоді як інші можуть бути реалізовані лише за наявності відповідних досліджень фахівців у галузях медицини, психології, управління персоналом тощо. Тільки після визначення необхідних рекомендацій указані напрями можуть знайти своє втілення у законодавчих чи локальних актах. Тому, дослідження психосоціальних ризиків на роботі потребує міждисциплінарного підходу, що дозволить передбачити найефективніші шляхи до гарантування й забезпечення психологічних умов праці.

Для інтеграції психосоціальних ризиків у систему управління охороною праці необхідним є детальне дослідження їх місця та ролі серед умов праці для різних видів трудової діяльності. Водночас, в аналізованій доповіді МОП 2019 р. важлива увага приділяється необхідності виявлення ситуацій та практик у сфрері зайнятості, які впливають на стрес та встановлення його наслідків для психічного здоров'я, наприклад, біомаркерів діагностики рівнів стресу [4, с. 56].

Закон України "Про охорону праці", визначаючи елементи управління охороною праці у ст. 13 [16], не регламентує питання попередження чи мінімізації впливу психосоціальних ризиків. Тому, зазначена стаття повинна бути конкретизована в частині визначення заходів щодо забезпечення психологічних умов праці. Так, наприклад, у контексті такого елемента управління охороною праці, як створення відповідних служб, що забезпечують вирішення конкретних питань охорони праці, слушною $є$ пропозиція щодо "законодавчого закріплення соціальної служби підприємства, установи, організації" [15, с. 237]. Серед повноважень такої служби, (які мають важливе значення в контексті протидії психосоціальним небезпекам) пропонуються, зокрема, надання індивідуальних і групових психологічних послуг працівникам, проведення соціально-психологічного консультування щодо адаптації у виробничому середовищі, подолання його негативних впливів, поліпшення стосунків у колективі тощо [15, с. 237].

Також у системі управління охороною праці згідно ст. 13 Закону "Про охорону праці" визначено ряд заходів, які можуть бути застосовані і в контексті забезпечення належних психологічних умов праці:

- забезпечення виконання необхідних профрілактичних заходів відповідно до обставин, що змінюються (такі заходи повинні проводитись, зокрема, і для профілактики стресу, професійного вигорання, мобінгу та домагань на робочому місці);

- упровадження прогресивних технологій, досягнень науки і техніки (зокрема, упровадження результатів як психології та медицини в контексті протидії психосоціальним небезпекам, так і менеджменту, управління персоналом для підвищення ефективності організації праці, що, як зазначалось вище, також значною мірою впливає на психоемоційний стан працівника). Як наголошує МОП, нові тенденції в організації праці, де працівники все частіше працюють автономно або далеко від приміщень свого роботодавця, потребують переосмислення поточного управління охороною праці, законів, політик та програм [4, с. 56];

- забезпечення усунення причин, що призводять до нещасних випадків, професійних захворювань, та здійснення профрілактичних заходів, визначених комісіями за підсумками розслідування цих причин (серед таких причин значне місце посідають психосоціальні ризики, зокрема втома, стрес, вигорання тощо);

- організація проведення аудиту охорони праці та за його підсумками вжиття заходів щодо усунення небезпечних і шкідливих для здоров'я виробничих фракторів (аналіз психологічного клімату в колективі, на нашу думку, повинен стати обов'язковою складовою відповідного аудиту);

- організація пропаганди безпечних методів праці та співробітництво із працівниками у галузі охорони праці. Так, з позиції МОП, захист психічного здоров'я працівників $є$ більш ефективним, якщо він оснований на профрілактичних стратегіях, зокрема за допомогою психосоціальних оцінок ризику та управління ними 3 метою запобігання стресам та психічним захворюванням, зумовленим роботою [5, с. 5]. Відповідно, важливою тенденцією розвитку міжнародних стандартів у сфрері охорони праці є зміщення акцентів в управлінні охороною праці на превентивний механізм. У Глобальній стратегії з охорони праці МОП наголошено на необхідності побудови та підтримки національної культури профілактики в галузі безпеки і гігієни праці [2], яка, згідно зі ст. 1 Конвенції МОП № 187, про основи, що сприяють безпеці та гігієні праці, означає культуру, в якій право на безпечне і здорове виробниче середовище дотримується на всіх рівнях, коли уряди, роботодавці і працівники беруть активну участь в забезпеченні безпечного і здорового виробничого середовища за допомогою системи встановлених прав, відповідальності й обов'язків та коли принципам профрілактики надається найвищий пріоритет [17].

Сучасні ризики для психологічної безпеки працівників. У звіті "Safety and health at the heart of the future of work. Building on 100 years of experience" визначено чотири ключові чинники, які створюють нові виклики для змін у правовому регулюванні охорони праці: технології, демографрія, сталий розвиток (включаючи зміни клімату), зміни в організації праці [4]. Щодо психологічних умов праці, найбільший вплив на них здійснюють, на нашу думку, технологічні трансформації та зміни в організації праці.

Так, відповідно до звіту, технологічні зміни створюють, зокрема, такі додаткові ризики:

1) для психологічного здоров'я працівника: а) зменшення балансу між роботою й особистим життям (зокрема, через збільшення можливостей для працівника "бути доступним" у будь-який час); б) ізоляція та відсутність соціальної взаємодії (при віддаленій роботі); в) технострес та інформаційне перевантаження;

2) для психологічної безпеки та приватності: а) розширення можливостей доступу до конфіденційної інформації про працівника; б) кібербулінг та кіберагресія;

3) ергономічні ризики: а) збільшення використання мобільних пристроїв та інші форми взаємодії людинамашина; б) сидяча робота, що призводить до підвищення ризику супутніх проблем зі здоров'ям (зорова втома, ожиріння, серцево-судинні захворювання тощо);

4) новітні ризики: а) електромагнітні поля; б) автоматизація та робототехніка; в) нанотехнології [4, с. 32, 34].

Щодо змін в організації праці, то на психологічне здоров'я працівника впливають, у першу чергу, такі:

1) наднормовий робочий час (з яким пов'язують, у першу чергу, хронічну втому, що може призвести до проблем зі здоров'ям, таких як серцево-судинні захворювання, шлунково-кишкові розлади, погіршення стану психічного здоров'я, включаючи вищі показники тривожності, депресії та розладів сну [4, с. 49]; 
2) нестандартні форми зайнятості, що створюють такі умови: а) для психосоціальних ризиків (наприклад, відчуття незахищеності та нестабільності при строкових трудових відносинах чи неповній зайнятості); б) підвищені ризики домагань (harassment); в) незахищеність від гірших умов праці (зокрема, у сфрері охорони праці); г) проблеми втоми [4, с. 50];

3) робота на цифрових платформах: а) працівникам не надаються, або надаються меншою мірою традиційні трудові гарантії (обмеження робочого часу, відпустки, оплата тимчасової непрацездатності тощо); б) оцінка ризиків під час виконання трудових обов'язків, як правило, відсутня; в) працівники самостійно несуть відповідальність за власну безпеку, за страхування життя і здоров'я [4, с. 54].

Указані чинники потребують детального вивчення: аналізу стану їх нормативної регламентації та особливостей реалізації, зарубіжного досвіду у цій сфрері, тому будуть предметом окремого наукового дослідження.

Протидія моральним переслідуванням. У контексті психологічних умов праці важливе значення має протидія моральним переслідуванням на робочому місці: мобінгу/булінгу, домаганням тощо. МОП протягом тривалого часу вказувала на необхідність протидії будь яким моральним переслідуванням на роботі, зокрема, у доповідях "Stress Prevention at Work Checkpoints. Practical improvements for stress prevention in the workplace" (2012), "Code of conduct and guidelines to prevent and address sexual harassment in workplace" (2016), "The Threat of Physical and Psychosocial Violence and Harassment in Digitalized Work" (2018) тощо. У преамбулі Декларації століття МОП щодо майбутнього сфери праці 2019 р. наголошено на необхідності забезпечення вільного від насильства та домагань світу праці [3].

У теорії національного трудового права до морального переслідування на робочому місці відносять будьякі дії, направлені на погіршення матеріальних умов праці, а також людських і міжособистісних стосунків одного або декількох потерпілих, які порушують їх права чи посягають на гідність і можуть суттєво пошкодити стан здоров'я та їх професійне майбутнє [15, с. 235].

На думку М. М. Шумила, мобінг - це різновид психологічного тиску або психологічного терору працівника, що полягає в систематичному, тривалому приниженні, зневажанні, ігноруванні, обструкції, необґрунтованій критиці, сексуальному домаганні, насміханні як на робочому місці, так і за його межами з боку інших співробітників або керівництва з метою доведення особи до стану неможливості здійснювати свою трудову функцію і подальшого звільнення за власним бажанням [18, c. 338]. У цілому підтримуючи дане тлумачення, дискусійною вважаємо позицію вченого, що метою мобінгу завжди є спонукання працівника до звільнення, хоча дійсно це одна $з$ найпоширеніших причин морального переслідування. Наприклад, Т. А. Коляда звертає увагу на те, що мобінг часто застосовується як спосіб позбавлення від небажаних працівників - керівник, маючи можливість застосування персонально-кадрових та дисциплінарних засобів, допускає дискримінацію досвідчених і висококваліфікованих підлеглих [19, с. 156].

Нормативне підґрунтя для заборони моральних переслідувань на робочому місці в Україні практично відсутнє. Так, ст. 28 Конституції України передбачає, що ніхто не може бути підданий такому, що принижує його гідність, поводженню [10], Закон України "Про засади запобігання та протидії дискримінації в Україні" обмежується тлумаченням поняття "утиск" (небажана для особи та/або групи осіб поведінка, метою або наслідком якої є приниження їх людської гідності за певними ознаками або створення стосовно такої особи чи групи осіб напруженої, ворожої, образливої або зневажливої атмосфери) та визначенням його формою дискримінації [20, ст. 1, 5]. При цьому терміни "переслідування" та "утиски" можна вживати як тотожні, оскільки згідно зі Словником синонімів української мови, переслідувати означає завдавати утисків [21, с. 171], хоча перший із них вважаємо влучнішим перекладом англійського терміну "harassment". Необхідність недопущення сексуальних домагань передбачено Законом "Про забезпечення рівних прав та можливостей жінок і чоловіків" [22, ст. 17].

Водночас, в аспекті поширеності утисків стосовно працівників загальної заборони здійснення таких дій без визначення механізму реалізації відповідних норм недостатньо. У зарубіжних країнах проблема переслідувань на робочому місці вирішується, як правило, саме в контексті забезпечення права на справедливі та безпечні умови праці, тоді як у національному законодавстві зберігається розуміння охорони праці виключно як дотримання норм техніки безпеки, виробничої санітарії. Як слушно зауважує О. В. Тищенко, досвід країн, де були прийняті закони щодо морального переслідування на роботі (Франції, Німеччини, Швеції, Данії тощо), засвідчує, факт їх прийняття сприяв породженню у суспільстві впевненості, що у випадку переслідувань на роботі, $є$ можливість через суд дієво захистити свої права [23, с. 66].

Тому, право на здорові та безпечні умови праці, закріплене ст. 2 Кодексу законів про працю України, повинно включати забезпечення роботодавцем не лише фрізичних, а і психологічних умов праці. Пропонується закріпити у Кодексі норму, згідно з якою гарантуватиметься "право на належні, безпечні і здорові умови праці, включаючи право на отримання інформації щодо умов праці та вимог охорони праці на робочому місці, на захист від психологічного переслідування у процесі виконання трудової функції, а також право на відмову від виконання роботи в умовах, що не відповідають вимогам охорони праці" [24, с. 117]. Пропонуємо запозичити позитивний досвід Болгарії в контексті протидії моральним переслідуванням, передбачивши обов'язок роботодавця, який отримав скаргу від працівника щодо утисків, негайно провести перевірку, вжити заходів для їх припинення і накласти дисциплінарне стягнення, якщо утиски спостерігалися з боку когось із працівників. У протилежному випадку відповідальність за бездіяльність покладається і на роботодавця [25, с. 196].

Слушною $є$ пропозиція І. В. Лагутіної щодо необхідності заборони морального переслідування і у правилах внутрішнього розпорядку [26, с. 742]. Здійсненням профілактики стосовно запобігання негативним явищам у виробничому середовищі може займатись соціальна служба на підприємствах, в установах, організаціях, про яку зазначалось вище.

Протидія домаганням на робочому місці. У контексті забезпечення належного психологічного клімату важливе значення має і протидія домаганням у сфері праці. Так, сексуальні домагання $€$ однією з форм прояву гендерної дискримінації [24, с. 3]. Відповідно до ст. 1 Закону "Про забезпечення рівних прав та можливостей жінок і чоловіків" сексуальні домагання визначаються як дії сексуального характеру, виражені словесно або фрізично, що принижують чи ображають осіб, які перебувають у відносинах трудового, службового, матеріального чи іншого підпорядкування [22]. Погоджуємося з Т. Марценюк, що таке формулювання $€$ неповним, оскільки воно пе- 
редбачає лише вертикальні відносини (підпорядкування типу начальник-підлеглий), але не включає стосунки горизонтального типу (між колегами), серед яких також трапляються випадки сексуальних домагань [27, с. 18].

У межах МОП виділяють найуразливіших до цієї форми дискримінації працівників: щодо жінок, це зокрема молоді, залежні фінансово, самотні або розлучені, а також мігранти; чоловіки, які піддаються домаганням, як правило, є молодими людьми, особами нетрадиційної сексуальної орієнтації, а також ті, які належать до етнічних чи расових меншин [28, с. хіi]. В Україні статистичні дані щодо цієї категорії людей відсутні, оскільки їх жертви, як правило, не звертаються за захистом або відповідні дії не визнаються судами сексуальними домаганнями.

Тривалий час комплексне регулювання протидії домаганням у сфрері праці було відсутнє і серед актів міжнародних організацій. Лише 2019 р. МОП прийняла Конвенцію № 190 про ліквідацію насильства та домагань у світі праці та відповідну Рекомендацію № 206. Уперше на рівні міжнародного договору закріплено право на світ праці, вільний від насильства та домагань, існує чітка і єдина система запобігання насильству та домаганням та їх подоланню, заснована на інклюзивному, інтегрованому та гендерному підходах [29, с. 1]. У преамбулі Конвенції № 190 наголошено, що насильство та домагання у світі праці впливають на психологічне, фрізичне та сексуальне здоров'я, гідність, сімейне та соціальне середовище. Крім того, Конвенція визначає механізми протидії домашньому насильству, вказуючи, що воно також впливає на зайнятість, продуктивність праці, здоров'я та безпеку працівників. Тому ратифікація Україною Конвенції № 190 має важливе значення в контексті захисту працівників від психологічного насилля та дискримінації.

ВИСНОВКИ. Інститут охорони праці потребує переосмислення в сучасних умовах з огляду на необхідність створення правових основ для забезпечення належних психологічних умов праці. Психосоціальні ризики як фактори, що зумовлюють стрес на робочому місці, потребують міждисциплінарного дослідження фахівців у сорері права, медицини, психології, менеджменту та управління персоналом тощо. Лише комплексний підхід дозволить визначити найбільш ефективні рекомендації для встановлення належного психологічного клімату та забезпечення психологічної безпеки працівників у процесі роботи.

Для інтеграції психосоціальних ризиків у систему управління охороною праці необхідним $є$ детальне дослідження їх місця та ролі серед умов праці. У статті внесено пропозиції щодо вдосконалення Закону "Про охорону праці" з метою конкретизації заходів, які можуть бути застосовані для забезпечення належних психологічних умов праці. Пропонується закріпити у законодавстві право працівника на захист від психологічного переслідування у процесі виконання трудової функції та визначити правові механізми протидії мобінгу. 3 метою протидії домаганням на робочому місці важливе значення має ратифрікація Україною Конвенції МОП № 190.

Створення безпечного та комфортного виробничого середовища, покращення психологічного клімату в колективі значною мірою має локальний характер, тому повинно забезпечуватись, у першу чергу, за допомогою співпраці роботодавця і працівників. Держава, у свою чергу, має закріпити мінімальні гарантії щодо психологічної безпеки на робочому місці, а також сприяти проведенню міждисциплінарних досліджень, які встанов- люватимуть вплив психологічного клімату на продуктивність та ефрективність працівників.

Список використаних джерел

1. Work for a Brighter Future: report of the Global Commission on the Future of Work. - January, 2019. URL: ISBN 978-92-2-132796-7 (web pdf) (date of request: 01.09.20).

2. Global Strategy on Occupational Safety and Health. Conclusions adopted by the International Labour Conference. 91st Session. - 2003. URL: ISBN 92-2-116288-5 (web version) (date of request: 01.09.20).

3. ILO Centenary Declaration for the Future of Work June 21, 2019. URL: https://www.ilo.org/wcmsp5/groups/public/@ed norm/@relconf/documents/ meetingdocument/wcms 711674.pdf (date of request: 01.09.20).

4. Safety and health at the heart of the future of work. Building on 100 years of experience. ILO, 2019. ISBN: 978-92-2-133152-0 (web pdf) (date of request: 01.09.20).

5. Workplace Stress: A collective challenge. Report. ILO, 2016. URL: 978-92-2-130642-9 (web pdf) (date of request: 01.09.20).

6. Професійне вигорання - явище, а не хвороба: що насправді затвердили в MKX-11. URL: https://moz.gov.ua/article/news/profesijnevigorannja---javische-a-ne-hvoroba-scho-naspravdi-zatverdili-v-mkh-11 (дата звернення: 01.09.20).

7. Губа Н. О. Психологічні чинники рівня задоволеності працею персоналу страхових компаній / Н. О. Губа, В. С. Кондратенко // Проблеми сучасної психології : збірник наук. пр. - 2017. - № 2(12). - С. 17-22.

8. Конвенція Міжнародної організації праці № 155 про безпеку й гігієну праці та виробниче середовище 1981 року. URL: https://zakon.rada.gov.ua/laws/show/993 050 (дата звернення: 01.09.20).

9. Конвенція Міжнародної організації праці № 161 про служби гігієни праці 1985 року. URL: https://zakon.rada.gov.ua/laws/show/993_042 (дата звернення: 01.09.20)

10. Конституція України в редакції від 01.01.2020 // Відомості Верховної Ради України. URL: https://zakon.rada.gov.ua/laws/show/254\% D0\%BA/96-\%D0\%B2\%D1\%80\#Text (дата звернення: 01.09.20).

11. Кодекс законів про працю України в редакції від 02.04.2020. URL: https://zakon.rada.gov.ua/laws/show/322-08\#Text (дата звернення: 01.09.20).

12. Цілі сталого розвитку 2016-2030, затверджені Генеральною Асамблеєю ОOH 2015 p. URL: http://www.un.org.ua/ua/tsili-rozvytkutysiacholittia/tsili-staloho-rozvytku (дата звернення: 01.09.20).

13. Вишновецька С. В. Основні фактори, що складають загрозу безпеці працівника під час трудової діяльності / С. В. Вишновецька // Соціальне право. - 2017. - № 2. - С. 30-37.

14. Яковлєв О. А. Правові засади встановлення умов праці за трудовим законодавством України : дис. ... д-ра юрид. наук : 12.00 .05 "Трудове право; право соціального забезпечення" / О. А. ЯковлєВ. - Х., 2019. - 460 c

15. Курс порівняльного трудового права: підручник у 2 т. Т. 2 / за ред. А. Р. Мацюка. - 2-ге вид., змін. і допов. Х. : Діса плюс, 2015. - 744 с.

16. Про охорону праці: Закон України від 14 жовтня 1992 року зі змінами та доповненнями. URL: https://zakon.rada.gov.ua/laws/show/ 2694-12\#Техt (дата звернення: 01.09.20).

17. Конвенція Міжнародної організації праці № 187 про основи, що сприяють безпеці та гігієні праці 2006 року // Інформаційний бюлетень 3 охорони праці. - 2007. - № 1 .

18. Велика українська юридична енциклопедія: у 20 т. Т. 11. Трудове право / редкол. : С. М. Прилипко, М. І. Іншин, О. М. Ярошенко та ін. Х. : Право, 2018. - 776 с.

19. Коляда Т. А. Мобінг у трудових (службово-трудових) відносинах: до постановки проблеми / Т. А. Коляда // Вісник Харківського нац. ун-ту внутрішніх справ. - 2010. - Вип. 2(49). - С. 152-161.

20. Про засади запобігання та протидії дискримінації в Україні: Закон України від 6 вересня 2012 року № 5207-VI // Офріційний вісник України. - 2012. - № 76. - Ст. 3071.

21. Словник синонімів української мови / А. А. Бурячок, Г. М. Гнатюк, С. І. Головащук та ін. У 2 т. Т. 2. - К. : Наук. думка, 2006. - 960 с.

22. Про забезпечення рівних прав та можливостей жінок і чоловіків: Закон України від 8 вересня 2005 року № 2866-IV // Відомості Верховної Ради України. - 2005. - № 52. - Ст. 561.

23. Тищенко О. В. Явище мобінгу в трудових правовідносинах: реалії сьогодення / О.В. Тищенко // Бюлетень Міністерства юстиції України. - 2008. - № 6 (80). - С. 62-67.

24. Закон о защите от дискриминации Болгарии, утвержден Парламентом 16 сентября 2003 г. Защита личности от дискриминации. В 3 т. Т. 1. - М. : Новая юстиция, 2009. - С. 191-210.

25. Лагутіна І. В. Захист трудових прав працівників Уповноваженим Верховної Ради України з прав людини / І. В. Лагутіна // Актуальні проблеми держави і права. - 2006. - Вип. 30. - С. 63-67.

26. Сахарук I. С. Недопущення дискримінації у сфері праці як принцип трудового права : дис. ... канд. юрид. наук: 12.00 .05 "Трудове право; право соціального забезпечення" / І. С. Сахарук. - К., 2012. - 230 с.

27. Марценюк Т. Гендерна дискримінація на ринку праці в Україні: соціологічний аналіз / Т. Марценюк // Праця і закон. - 2008. - № 2. C. $16-19$.

28. Рівність у сфері праці - виклик зберігається // Глобальна доповідь МОП, представлена відповідно до механізму реалізації Декларації 
МОП про основоположні принципи і права у сфері праці. - 2011. - 82 с. URL: http://www.ilo.org (дата звернення: 01.09.20).

29. Eliminating Violence and Harassment in the World of Work: Convention No.190, Recommendation No.206, and the accompanying Resolution. ILO, 2019. URL: ISBN: 978-92-2-133887-1 (web pdf) (date of request: 01.09.20).

\section{References}

1. Work for a Brighter Future: report of the Global Commission on the Future of Work. January, 2019. URL: ISBN 978-92-2-132796-7 (web pdf) (date of request: 01.09.20). (in English)

2. Global Strategy on Occupational Safety and Health. Conclusions adopted by the International Labour Conference. 91st Session. 2003. URL: ISBN 92-2-116288-5 (web version) (date of request: 01.09.20). (in English)

3. ILO Centenary Declaration for the Future of Work June 21, 2019. URL: https://www.ilo.org/wcmsp5/groups/public/@ed norm/@relconf/documents/ meetingdocument/wcms 711674.pdf (date of request: 01.09.20). (in English)

4. Safety and health at the heart of the future of work. Building on 100 years of experience. ILO, 2019. ISBN: 978-92-2-133152-0 (web pdf) (date of request: 01.09.20). (in English)

5. Workplace Stress: A collective challenge. Report. ILO, 2016. URL: 978-92-2-130642-9 (web pdf) (date of request: 01.09.20). (in English)

6. Profesijne vygorannja - javyshhe, a ne hvoroba: shho naspravdi zatverdyly v MKH-11. URL: https://moz.gov.ua/article/news/profesijnevigorannja---javische-a-ne-hvoroba-scho-naspravdi-zatverdili-v-mkh-11 (data zvernennja: 01.09.20). (in Ukrainian)

7. Guba N.O., Kondratenko V.S. Psyhologichni chynnyky rivnja zadovolenosti praceju personalu strahovyh kompanij(Psychological factors of the level of job satisfaction of insurance companies). Zbirnyk naukovyh prac "Problemy suchasnoi' psyhologii"'. 2017. № 2(12). S.17-22. (in Ukrainian)

8. Konvencija Mizhnarodnoi' organizacii' praci № 155 pro bezpeku gigijenu praci ta vyrobnyche seredovyshhe 1981 roku. URL: https://zakon.rada.gov.ua/laws/show/993_050 (data zvernennja: 01.09.20). (in Ukrainian)

9. Konvencija Mizhnarodnoi' organizacii' praci №161 pro sluzhby gigijeny praci 1985 roku. URL: https://zakon.rada.gov.ua/laws/show/ 993_042 (data zvernennja: 01.09.20). (in Ukrainian)

10. Konstytucija Ukrai'ny $v$ redakcii' vid 01.01.2020. Vidomost Verhovnoi' Rady Ukrai'ny. 1996. № 30. St. 141. (in Ukrainian)

11. Kodeks zakoniv pro pracju Ukrai'ny $v$ redakcii' vid 02.04.2020. URL: https://zakon.rada.gov.ua/laws/show/322-08\#Text (data zvernennja: 01.09.20). (in Ukrainian)

12. Cili stalogo rozvytku 2016-2030, zatverdzheni General'noju Asamblejeju OON 2015 r. URL: http://www.un.org.ua/ua/tsili-rozvytkutysiacholittia/tsili-staloho-rozvytku (data zvernennja: 01.09.20). (in Ukrainian)

13. Vyshnovec'ka S.V. Osnovni faktory, shho skladajut' zagrozu bezpeci pracivnyka pid chas trudovoi' dijal'nosti(The main factors that threaten the safety of the employee during employment). Social'ne pravo. 2017. №2. S.30-37. (in Ukrainian)

14. Jakovljev O.A. Pravovi zasady vstanovlennja umov praci za trudovym zakonodavstvom Ukrai'ny(Legal bases of establishment of working conditions according to the labor legislation of Ukraine): dys. dokt. juryd. nauk. / 12.00.05 "Trudove pravo; pravo social'nogo zabezpechennja". H., 2019. 460 s. (in Ukrainian)

15. Kurs porivnjal'nogo trudovogo prava(Course of comparative labor law): pidruchnyk u 2 tomah / za red. A.R. Macjuka. 2-ge vyd., zmin. i dop. Harkiv: Disa pljus, 2015. T.2. 744 s.(in Ukrainian)

16. Pro ohoronu praci: Zakon Ukrai'ny vid 14 zhovtnja 1992 roku zi zminamy ta dopovnennjamy. URL: https://zakon.rada.gov.ua/laws/show/ 2694-12\#Text (data zvernennja: 01.09.20). (in Ukrainian)

I. Sakharuk, PhD (Law), Associate Prof.

Taras Shevchenko National University of Kyiv, Kyiv, Ukraine

\section{TRENDS IN LEGAL REGULATION FOR PSYCHOSOCIAL RISKS AT WORK}

The article examines the psychosocial risks as an element of the occupational safety and health system. The author outlines that competition, higher expectations for productivity and working hours and other psychosocial hazards have resulted in increasingly stressful work environment. The legal grounds for psychological working conditions regulation are analysed. The author determines the recommendations for improving the legislation on occupational safety and health. The analysis of the main psychosocial risks is carried out.

The paper substantiates the main directions for the improvement of occupational safety and health management systems. They include the integration of psychosocial risks in risk assessment for developing strategies for prevention and management of hazards; the ways to develop a safe psychological climate at the workplace; determining the impact of psychosocial risks at work on the physical health of employees; determining the correlation of overtime and sedentary work on the health of employees.

The basic technological transformations and changes in the organization of work which influence the psychological safety of employees are investigated. The main risks to the employee's psychological health have been identified. They are 1) reduction of work-life balance; 2) isolation and lack of social interaction; 3) technostress and information overload; 4) expanding access to confidential information about the employee; 5) overtime; 6) non-standard forms of employment, 7) work on digital platforms. Particular attention is paid to counteracting mobbing and harassment at work.

Keywords: working conditions, occupational safety and health, psychosocial risks, psychological working conditions, psychological safety, psychological climate, non-standard working conditions, digital platforms, mobbing, harassment 